\title{
Cerebral $\mathrm{O}_{2}$ Supply Thresholds for the Preservation of Electrocortical Brain Activity During Hypotension in Near-Term-Born Lambs
}

\author{
SANDRA VAN OS, DJIEN LIEM, JEROEN HOPMAN, JOHN KLAESSENS, AND \\ MARGOT VAN DE BOR \\ Division of Neonatology [S.v.O., D.L., M.v.d.B.] and Clinical Physics [J.H., J.K.], Department of \\ Pediatrics, University Medical Center Nijmegen, Nijmegen, The Netherlands
}

\begin{abstract}
ABST
The fetal brain develops rapidly during the last trimester of
pregnancy. Therefore, the brain of infants who are born preterm
is vulnerable to changes in oxygen and nutrient supply in the
neonatal period. The objective was to determine the effect of
gestational age (GA) on the cerebral $\mathrm{O}_{2}$ supply threshold level
for preservation of brain function during hypotension in near-
term-born lambs. Lambs were delivered at 141 or $127 \mathrm{~d}$ of
gestation. Hypotension was induced by stepwise withdrawal of
blood. Mean arterial blood pressure (MABP) baseline levels
were 63.2 (6.4) in 141-d and 54.4 (15.5) mm Hg in 127-d lambs.
The MABP threshold below which MABP and blood flow in the
left carotid artery were linearly related was 36.1 (13.1) mm Hg in
141-d lambs. In 127-d lambs, MABP and blood flow in the left
carotid artery were linearly related over the whole range of
recorded MABP values. Electrocortical brain activity (ECBA)
was used as a measure of brain function. Thresholds of MABP
for maintenance of ECBA were reached at, respectively, $31.6 \%$
(4.9\%) of baseline in 141-d and $61.9 \%$ (13.0\%) of baseline
\end{abstract}
Approximately $2 \%$ of all newborns in the Netherlands are born before 32 completed weeks of gestation. Although mortality rates have decreased over the past $15 \mathrm{y}$, long-term morbidity has not changed (1). Because the fetal brain develops very rapidly during the last trimester of pregnancy, the brain of infants who are born preterm is very vulnerable to changes in oxygen and nutrient supply in the neonatal period.

Brain cells need a sufficient amount of oxygen for function, growth, and development. Cerebral $\mathrm{O}_{2}$ supply is determined by the arterial oxygen content $\left(\mathrm{CaO}_{2}\right)$ and cerebral blood flow $(\mathrm{CBF})$. If cerebral autoregulation is impaired, then hypotension results in low $\mathrm{CBF}$ and leads to decreases in cerebral $\mathrm{O}_{2}$ supply. When cerebral $\mathrm{O}_{2}$ supply becomes insufficient to meet the cellular

Received May 3, 2004; accepted August 18, 2004.

Correspondence: Margot van de Bor, M.D., Ph.D., Department of Pediatrics 435, University Medical Center Nijmegen, P.O. Box 9101, 6500 HB Nijmegen; e-mail: m.vandebor@cukz.umcn.nl.

DOI: 10.1203/01.PDR.0000153673.00627.F4
MABP in 127-d lambs. However, thresholds of cerebral $\mathrm{O}_{2}$ supply for maintenance of ECBA were similar in both GA groups. We conclude that thresholds of cerebral $\mathrm{O}_{2}$ supply for maintenance of brain cell function are independent of GA but are reached at higher MABP levels in 127-d than in 141-d lambs and therefore places the sick preterm infant easily at risk for ischemic cerebral injury. (Pediatr Res 57: 358-362, 2005)

\section{Abbreviations}

$\mathrm{CaO}_{2}$, content of arterial oxygen

CBF, cerebral blood flow

CFM, cerebral function monitor

$\mathrm{Cvo}_{2}$, content of venous oxygen

ECBA, electrocortical brain activity

EEG, electroencephalogram

GA, gestational age

MABP, mean arterial blood pressure

Qcar, blood flow in left carotid artery demand for oxygen, a sequence of events will be triggered, eventually leading to neonatal brain cell dysfunction or damage.

EEG features provide information on brain cell function (2). Energy failure in the brain, e.g. as a result of reduced cerebral $\mathrm{O}_{2}$ supply during hemorrhagic hypotension, leads to a blockade of neuronal synaptic function and reduced electrical firing of neurons. A disadvantage of conventional EEG is that it requires the presence of an expert to interpret the large volumes of data. In an effort to solve this problem, various methods of compressing the EEG signal have been developed, the cerebral function monitor (CFM) being one of them. CFM correlates well with conventional multichannel EEG evaluation of cortical neuronal activity in neonates, except for the recognition of very short seizure activity patterns (3-8). Noninvasive recording of electrocortical brain activity (ECBA) by means of CFM-like signals can be used as a measure for brain cell function in the newborn period (2). Abnormal tracings are indicative of the risk for neonatal death and in the survivors to neurodevelopmental outcome (3,9-12). 
Coupling between CBF and EEG features has been observed during sleep $(13,14)$, seizures $(15,16)$, electrical stimulation (17), and cerebral ischemia (18), but thresholds of CBF and cerebral $\mathrm{O}_{2}$ supply below which electrical brain dysfunction occurs during hemorrhagic hypotension have not yet been defined in near-term-born humans and animals. Therefore, the aim of this study was to determine the effect of gestational age (GA) on the cerebral $\mathrm{O}_{2}$ supply threshold level for the preservation of ECBA during hemorrhagic hypotension in near-termborn lambs. On the basis of a previous study (19) of near-termborn lambs under hypoxemic conditions, we hypothesized that the threshold level of cerebral $\mathrm{O}_{2}$ supply for the preservation of ECBA is equal in lambs of 141 and $127 \mathrm{~d}$ of gestation.

\section{METHODS}

Animal preparation and instrumentation. Pregnant ewes of Dutch Texel breed were operated on at $141 \mathrm{~d}(n=6)$ or $127 \mathrm{~d}(n=6)$ of gestation (term $147 \mathrm{~d}$ ) under general anesthesia with $3 \%$ isoflurane. After a polyvinyl catheter was inserted into the ewe's jugular vein, isoflurane anesthesia was replaced with infusion of $600 \mathrm{mg} / \mathrm{h}$ of ketamine hydrochloride and $15 \mathrm{mg} / \mathrm{h}$ of midazolam. The pregnant horn of the uterus was exposed through a midline incision in the ewe's abdomen, and a uterus incision was made over the fetal head.

The fetus's head and right forelimb were delivered, and an occluder was placed around the umbilical cord but was not clamped yet. A polyvinyl catheter (OD: $2.1 \mathrm{~mm}$ ) was placed in the right brachial vein for administration of ketamine hydrochloride $\left(10 \mathrm{mg} \cdot \mathrm{kg}^{-1} \cdot \mathrm{h}^{-1}\right)$, glucose $5 \%\left(2 \mathrm{~mL} \cdot \mathrm{kg}^{-1} \cdot \mathrm{h}^{-1}\right)$, and antibiotics (amoxicillin and gentamycin). Furthermore, the right brachial artery (polyvinyl catheter, OD: $2.1 \mathrm{~mm}$, with its catheter tip in the arcus aortae) and right jugular vein (polyvinyl catheter OD: $2.1 \mathrm{~mm}$ ) were cannulated for measurement of the arterial blood pressure and arterial and venous blood gas sampling. The venous catheter was inserted in the cranial direction of the right jugular vein to access the venous cerebral compartment to calculate the venous oxygen content $\left(\mathrm{CVO}_{2}\right)(19-21)$. Mean arterial blood pressure (MABP) was measured with disposable transducers (Edwards Life Sciences BV, Los Angeles, CA). Arterial and venous blood gases were analyzed with a multiwavelength blood gas analyzer (ABL 510; Radiometer Medical A/S, Copenhagen, Denmark). Oxygen saturation values were corrected for interspecies differences according to Nijland et al. (22).

After exposing the left carotid artery, we applied an appropriately sized perivascular ultrasonic blood flow transducer (2SL, S or B; Transonic System, New York, NY) to fit around the vessel to measure the carotid artery blood flow (Qcar). Changes in Qcar were used to assess changes in CBF. A close linear relationship between $\mathrm{Qcar}$ and $\mathrm{CBF}$, determined with radioactive microspheres, was reported by Van $\mathrm{Bel}$ et al. (23).

Cerebral $\mathrm{O}_{2}$ supply and cerebral $\mathrm{O}_{2}$ consumption were, respectively, calculated as follows:

$\mathrm{O}_{2}$ supply $\left(\mathrm{mL} \mathrm{O}_{2} / \mathrm{min}\right)=\mathrm{Qcar} \times \mathrm{CaO}_{2}$

$\mathrm{O}_{2}$ consumption $(\mathrm{mL} \mathrm{O} / \mathrm{min})=\mathrm{Qcar} \times\left(\mathrm{CaO}_{2}-\mathrm{CvO}_{2}\right)$

Arterial (venous) oxygen content was calculated as follows:

$\mathrm{Ca}(\mathrm{v}) \mathrm{O}_{2}\left(\mathrm{~mL} \mathrm{O}_{2} / \mathrm{mL}\right)=\mathrm{Sa}(\mathrm{v}) \mathrm{O}_{2} \times \mathrm{Hb}(\mathrm{g} / \mathrm{dL}) \times 1.36\left(\mathrm{~mL} \mathrm{O}_{2} / \mathrm{g} \mathrm{Hb}\right) / 100$

Two disposable subdermal needle electrodes for EEG recordings (Oxford Instruments BV, Gorinchem, the Netherlands) were positioned on the parietal regions of the skull, and one electrode was positioned on the occipital region as a reference. Thus, a CFM recording was registered. Conventional CFM provides a semilogarithmic amplitude distribution plot of a single channel EEG through amplification, bandpass filtering $(2-16 \mathrm{~Hz})$, compression, rectification, and smoothing. The signal then is plotted at slow speed and is very well suited for visual evaluation (24). Although many authors have tried to express electrical activity derived from the CFM signal on a numerical scale, calculating means from a semilogarithmic scale, in our opinion, is not a logical step in signal analysis. Therefore, from a signal analytical point of view, we used a slightly different approach. We also used a $2-$ to $16-\mathrm{Hz}$ band-filtered one-channel EEG, but we calculated the (3 min) mean of the squared signal (mean power). The result is presented as the root from this signal. ECBA thus is calculated as the root mean square value of a band-filtered $(2-16 \mathrm{~Hz})$ one-channel EEG $(19,21)$ and is comparable with a voltage scale.

Experimental procedures. After instrumentation, the lambs were intubated and ventilation was started using a continuous flow pressure-controlled ventilator (Babylog $1 \mathrm{HF}$; Dräger, Lübeck, Germany). Surfactant (Survanta; Ross Laboratories, Columbus, $\mathrm{OH}$ ) was administered when necessary to achieve adequate ventilation and oxygenation with a fraction of inspired oxygen of 0.30 .

When the lamb was in an optimal ventilatory (arterial oxygen pressure $10-14 \mathrm{kPa}$; arterial partial pressure of $\mathrm{CO}_{2} 4.5-6.0 \mathrm{kPa}$; $\mathrm{pH}$ 7.3-7.4; arterial oxygen percentage saturation $>90 \%$ ) and circulatory (MABP $50-65 \mathrm{~mm} \mathrm{Hg}$ ) condition, we clamped the umbilical cord to mimic an extrauterine condition. The physiologic measurements (MABP, Qcar, and ECBA) were recorded with a computer system and stored for further analysis (MIDAC; Biomedical Engineering Department, University Medical Center Nijmegen, Nijmegen, the Netherlands).

After a stabilization period of $3 \mathrm{~h}$, baseline values were determined. For obtaining graded hypotension, blood was withdrawn in a stepwise manner. Per step, $\sim 25 \mathrm{~mL} / \mathrm{kg}$ was removed to reach a 5-10 $\mathrm{mm} \mathrm{Hg} \mathrm{MABP}$ reduction. Each level was maintained for $15 \mathrm{~min}$, at the end of which arterial and venous blood gases were determined.

Statistical analysis. Over the last 3 min of each MABP level, mean values were calculated for each variable. The mean of the left and right hemispheric ECBA was used for further analysis. Differences in baseline values of MABP, Qcar, $\mathrm{CaO}_{2}, \mathrm{O}_{2}$ supply, $\mathrm{O}_{2}$ consumption, ECBA, and threshold levels between the GA groups were assessed with Mann-Whitney $U$ tests.

The "best" prediction of a continuous dependent variable for any value of a continuous independent variable will be a line that minimizes the distance between the data and the fitted line. The standard method to approach the "best" prediction is called least-squares regression. When this method is used to fit a regression line, the sum of the squares of the vertical distances (residuals) of the observations from the line is minimized. Each distance is the difference for an individual between the observed value and the value given by the line, known as the fitted value (25). Therefore, the threshold values of the physiologic variables (MABP, Qcar, cerebral $\mathrm{O}_{2}$ supply) were determined in the individual lambs by repetitively fitting a regression model of two straight lines through the data above and below a test point. The threshold was defined as the test point at which the total residual sum of squares from the two fitted lines was minimal $(19,26)$.

Statistical analyses were performed with the SPSS statistical package (version 10.0; SPSS Inc., Chicago, IL). The study was approved by the Institutional Animal Care and Use Committee of the University of Nijmegen before implementation.

\section{RESULTS}

During the experiments, the animals were kept in optimal ventilatory condition. Mean (SD) blood gas values of the individual lambs during the length of the experiments were as follows: arterial oxygen pressure $11.4(5.7) \mathrm{kPa}$, arterial partial pressure of $\mathrm{CO}_{2} 5.4 \mathrm{kPa}(1.2 \mathrm{kPa}), \mathrm{pH} 7.33(0.1)$, and arterial oxygen percentage saturation $90.9 \%$ (5.9\%). The mean (SD) $\mathrm{Hb}$ level decreased during the experiments from $10.9 \mathrm{~g} / \mathrm{dL}$ (3.1 $\mathrm{g} / \mathrm{dL})$ to $7.3 \mathrm{~g} / \mathrm{dL}(3.0 \mathrm{~g} / \mathrm{dL})$. Table 1 presents mean $(\mathrm{SD})$ baseline values of the physiologic variables (MABP, Qcar, $\mathrm{CaO}_{2}$, cerebral $\mathrm{O}_{2}$ supply, cerebral $\mathrm{O}_{2}$ consumption, and ECBA) in 141- and 127-d lambs.

For determining whether pooling of the data may have obscured evidence of threshold-like relationships between MABP and Qcar, data from the individual lambs in the two GA groups are shown in Fig. 1. In the 141-d lambs, all except one

Table 1. Mean (SD) baseline values of MABP, Qcar, $\mathrm{CaO}_{2}$, cerebral $\mathrm{O}_{2}$ supply, cerebral $\mathrm{O}_{2}$ consumption, and ECBA in 141and 127-d lambs

\begin{tabular}{lcc}
\hline & $\begin{array}{c}141 \mathrm{~d} \\
(n=6)\end{array}$ & $\begin{array}{c}127 \mathrm{~d} \\
(n=6)\end{array}$ \\
\hline $\mathrm{MABP}$ & $63.2(6.4)$ & $54.4(15.5)$ \\
$\mathrm{Qcar}(\mathrm{mL} / \mathrm{min})$ & $29.0(11.1)$ & $24.1(10.2)$ \\
$\mathrm{CaO}_{2}(\mathrm{~mL} \mathrm{O} / \mathrm{dL})$ & $12.4(4.0)$ & $16.7(3.7)$ \\
$\mathrm{O}_{2}$ supply $(\mathrm{mL} / \mathrm{min})$ & $4.1(2.4)$ & $3.7(1.1)$ \\
$\mathrm{O}_{2}$ consumption $(\mathrm{mL} / \mathrm{min})$ & $0.75(0.31)$ & $1.07(0.33)$ \\
$\mathrm{ECBA}(\mu \mathrm{V})$ & $13.3(4.9)$ & $7.6(3.0)^{*}$ \\
\hline
\end{tabular}

$* p<0.05$, Mann-Whitney $U$ test, $141 v s 127 \mathrm{~d}$. 

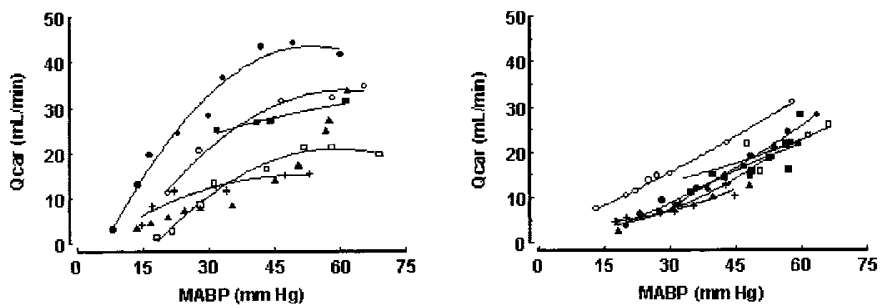

Figure 1. The relationship between MABP and Qcar 141-d (left) and 127-d (right) lambs.

lamb (ム) had a threshold-like relationship between MABP and Qcar. In one lamb (ם), we were unable to obtain MABP levels $<30 \mathrm{~mm} \mathrm{Hg}$. The mean (SD) MABP threshold for maintenance of Qcar was $36.1 \mathrm{~mm} \mathrm{Hg}(13.1 \mathrm{~mm} \mathrm{Hg})$ in the remaining 141-d lambs. In the 127-d lambs, we observed a linear relationship between Qcar and MABP in all lambs.

The relationship between MABP and ECBA in the 141- and $127-d$ lambs is presented in Fig. 2. Mean (SD) thresholds of MABP below which ECBA decreased were significantly ( $p<$ $0.05)$ different between the GA groups $(20.3 \mathrm{~mm} \mathrm{Hg}(4.1 \mathrm{~mm}$ $\mathrm{Hg})$ and $31.8 \mathrm{~mm} \mathrm{Hg}(9.2 \mathrm{~mm} \mathrm{Hg})$ in 141- and 127-d lambs, respectively). The threshold levels corresponded with $31.6 \%$ (4.9\%) of baseline MABP in the 141-d lambs and $61.9 \%$ $(13.0 \%)$ of baseline MABP in the 127-d lambs. In other words, threshold levels of MABP to preserve ECBA were reached when MABP decreased 68.4 and $38.1 \%$ of baseline in the 141and the 127-d lambs, respectively.

The relationship between Qcar and ECBA in the 141- and 127-d lambs is presented in Fig. 3. Mean (SD) thresholds of Qcar below which ECBA decreased were not statistically different between the GA groups: the overall threshold level in all lambs was $10.7 \mathrm{~mL} / \mathrm{min}(4.7 \mathrm{~mL} / \mathrm{min})$.

Figure 4 depicts the relationship between cerebral $\mathrm{O}_{2}$ supply and ECBA. Mean (SD) thresholds of cerebral $\mathrm{O}_{2}$ supply below which ECBA decreased were not statistically different between the GA groups: the overall threshold level in all lambs was $1.09 \mathrm{~mL} \mathrm{O}_{2} / \mathrm{min}\left(0.46 \mathrm{~mL} \mathrm{O}_{2} / \mathrm{min}\right)$. No clear relationship was observed between cerebral $\mathrm{O}_{2}$ consumption and ECBA in both GA groups.

\section{DISCUSSION}

During hemorrhagic hypotension, thresholds of CBF and cerebral $\mathrm{O}_{2}$ supply to preserve brain cell function did not differ

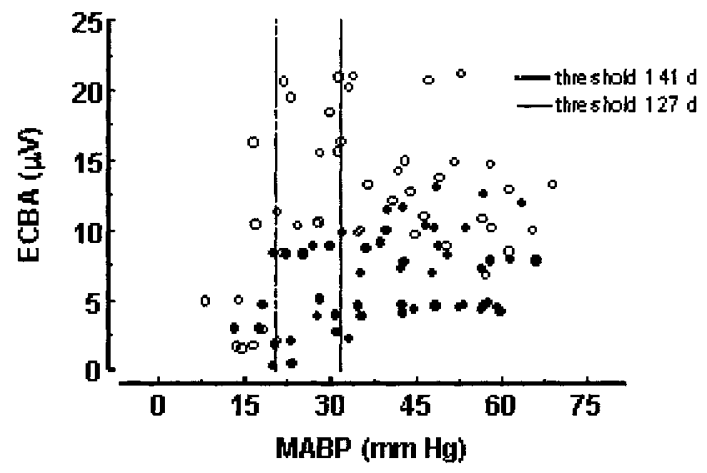

Figure 2. The relationship between MABP and ECBA in 141-d $(\bigcirc)$ and 127-d (-) lambs.

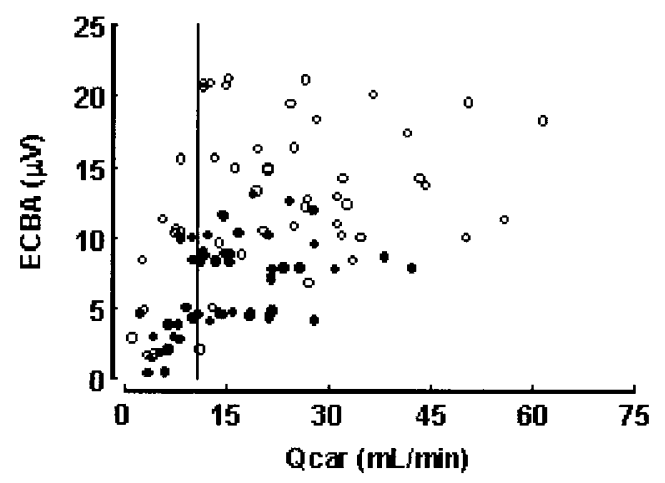

Figure 3. The relationship between Qcar and ECBA in 141-d $(\bigcirc)$ and 127-d (@) lambs

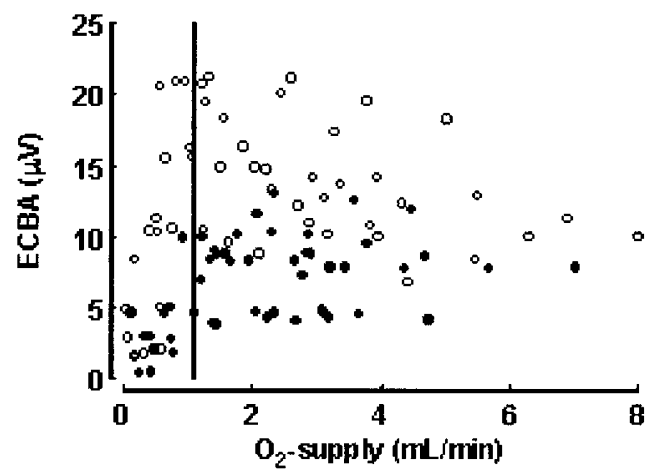

Figure 4. The relationship between cerebral $\mathrm{O}_{2}$ supply and ECBA in the 141-d (○) and 127-d (๑) lambs.

between 141- and 127-d lambs. We used near-term newborn lambs to study the effect of reduced cerebral $\mathrm{O}_{2}$ supply after hemorrhagic hypotension on electrical brain cell function. The newborn lamb model was chosen because brain development in fetal lambs in the last trimester of pregnancy is similar to that in the human fetus (27). Furthermore, there is extensive experience with cerebral hemodynamic studies in this animal model (27). However, when extrapolating the results from this study to the human situation, one must realize that this model does not fully mimic the complex pathology of hypotension in the human preterm infant.

In humans, a large(r) proportion of CBF is derived from the vertebral arteries, whereas in the sheep, flow is provided largely by the carotid arteries (28). The design of the study did not allow the use of microspheres to determine CBF. However, Qcar measured with a flow probe applied on the carotid artery provides an accurate prediction of $\mathrm{CBF}$, as determined with radioactive microspheres $(23,29,30)$.

Although this study was not designed to test the autoregulatory capacities of near-term-born lambs, a striking finding was that in all 127-d lambs, a linear relationship between MABP and CBF was found, whereas in the 141-d lambs, CBF was preserved over a (wide) range of MABP values. Although this linear relationship between MABP and Qcar in the 127-d lambs is probably due to impaired autoregulation, the possibility that this relationship is the result of insufficient cardiac output cannot be ruled out.

In sick preterm infants, low MABP during hemorrhagic hypotension may lead to impaired $\mathrm{CBF}$ and subsequent reduc- 
tion of cerebral $\mathrm{O}_{2}$ supply. A number of studies reported autoregulation of the CBF in a lamb model. The MABP values that corresponded to the lower limit of the autoregulatory plateau in these studies were reported to range between 30 and $45 \mathrm{~mm} \mathrm{Hg}$ for preterm and near-term fetal lambs (31-35), which is in accordance with the threshold value of MABP for maintenance of CBF that we observed in the 141-d born lambs. Although those studies were conducted earlier in gestation, they were performed in animals in an intrauterine situation and not exposed to birth stress. Birth stress may have abolished cerebral autoregulation during hemorrhagic hypotension in the $127-d$ lambs in our study. This observation is supported by the observed failure of cerebral autoregulation in some studies in preterm-born humans (36,37). However, Tsuji et al. (38) showed evidence of impaired autoregulation only in a subgroup of preterm infants who are at risk for developing germinal matrix-intraventricular hemorrhage and periventricular leukomalacia, whereas Tuszczuk et al. (39) observed that CBF, as measured with near infrared spectroscopy, was maintained across a wide range of MABP $(23.7-39.3 \mathrm{~mm} \mathrm{Hg})$ in preterm infants of $<34$ wk of gestation. Kissack et al. (40) demonstrated no relationship between the fractional oxygen extraction and MABP in preterm infants of $<32$ wk of gestation.

The threshold value of MABP for preservation of brain cell function was lower in the 141-d born lambs $(20.3 \mathrm{~mm} \mathrm{Hg})$ than in 127-d born lambs $(31.8 \mathrm{~mm} \mathrm{Hg})$, whereas baseline MABP levels were higher in the 141-d born lambs $(63.2 \mathrm{~mm} \mathrm{Hg})$ than in the 127-d born lambs (54.4 mm Hg). Thus, the MABP range (between baseline and threshold values) in which the brain is not at risk for functional damage as a result of insufficient perfusion was much broader in 141-d born lambs than in 127-d born lambs. In the 141-d lambs, MABP decreased to $68.4 \%$ of baseline before the critical threshold was reached, whereas in the $127-d$ lambs, MABP could decrease only to $38.1 \%$ of baseline until the threshold was reached.

Brain cell function was preserved at MABP levels below the threshold value for maintenance of Qcar in the 141-d lambs. The same phenomenon was also shown in newborn lambs by Van de Bor et al. (26). Below the threshold value of MABP for maintenance of $\mathrm{CBF}$, oxygen extraction increases when $\mathrm{CBF}$ falls (41) to preserve the amount of oxygen available for electrical firing of the neurons. This could explain the difference between the threshold MABP value for maintenance of $\mathrm{CBF}$ and the threshold MABP value for preservation of ECBA found in our study.

Low blood pressure, a common problem in the care of human preterm infants, usually arises from the interplay of ductal shunting, high or low vascular resistance, poor myocardial function, and interaction with positive pressure ventilation, and not only from blood or fluid loss (42). However, in the present study, hypotension was induced by withdrawal of blood. Laudignon et al. (43) observed in the newborn piglet a similar curve in the relationship between $\mathrm{CBF}$ and MABP when a balloon catheter was inflated in the aortic root of the aorta to induce hypotension.

As a result of the withdrawal of blood, hypotension was accompanied by anemia. The observed reduction in CBF after the induction of hemorrhagic hypotension may have been less pronounced because of the induced anemia for two reasons. A low $\mathrm{Hb}$ concentration is accompanied by a low $\mathrm{CaO}_{2}$ and low blood viscosity, which both reduce cerebral vascular resistance and therefore increase CBF $(19,44,45)$. However, O'Neill et al. (46) showed that the CBF response to hemorrhagic hypotension was not dependent on a change in hematocrit and, presumably, viscosity. Therefore, we assume that anemia has not disturbed cerebral regulation of CBF in our study.

Noninvasive recording of ECBA can be used as a measure of brain cell function (2). Low cerebral ECBA within hours after birth seems to be related to neuronal damage (47) but also to neonatal death and to impaired neurodevelopmental outcome $(12,48,49)$. Mean baseline values of ECBA differed significantly between the 141- and the 127-d born lambs. This is probably due to the differences in cortical thickness and number of synapses between lambs of different GAs. Thornberg and Thiringer (50) and Viniker et al. (51) also observed an increase in voltage with increasing GA. They contributed the change to the gradual increase in electrical activity during suppression periods in the "trace-alternant" pattern of the neonatal EEG.

Some controversy exists regarding the effect of ketamine on $\mathrm{CBF}$, metabolic rate of oxygen, and EEG. However, the usage of an anesthetic agent is a prerequisite from an ethical point of view and moreover prevents stress-induced activation of the brain (52). The use of low-dose ketamine $(2 \mathrm{mg} / \mathrm{kg})$ in lambs (53) and pigs (54) did not have any cardiovascular or cerebrovascular effect.

We conclude that despite similar thresholds of cerebral $\mathrm{O}_{2}$ supply for the preservation of brain cell function, the 127-d born lambs are more at risk for cerebral oxygen and nutrient supply disturbances as a result of low MABP than the 141-d born lambs are. This phenomenon is caused by the fact that the MABP threshold values for the preservation of cerebral $\mathrm{O}_{2}$ supply and therefore brain cell function are higher in the 127-d than in the 141-d lambs. Because reference values for MABP in newborn infants indicate lower MABP values for preterm infants $(55,56)$, one should be concerned whether maintenance of MABP in the recommended reference range might place the sick preterm infant easily at risk for brain cell damage as a result of inadequate cerebral perfusion and therefore inadequate cerebral $\mathrm{O}_{2}$ supply. Further study is needed to define the safe MABP range for preterm infants to minimize the risk for either cerebral hypoperfusion or hyperperfusion.

Acknowledgments. We thank Alex Hanssen, Theo Arts, and Fred Philipsen, Central Animal Laboratory Nijmegen, for advice and surgical assistance.

\section{REFERENCES}

1. Hack M, Friedman H, Fanaroff AA 1996 Outcomes of extremely low birth weight infants. Pediatrics 98:931-937

2. Prior PF, Maynard DE Monitoring Cerebral Function: Long-Term Recordings for Cerebral Electrical Activity. Elsevier Science Publishers B.V., Amsterdam, pp 1-366

3. Al Naqeeb N, Edwards AD, Cowan FM, Azzopardi D 1999 Assessment of neonatal encephalopathy by amplitude-integrated electroencephalography. Pediatrics 103:1263-1271

4. Greisen G 1994 Tape-recorded EEG and the cerebral function monitor: amplitudeintegrated, time-compressed EEG. J Perinat Med 22:541-546 
5. Hellstrom-Westas L 1992 Comparison between tape-recorded and amplitudeintegrated EEG monitoring in sick newborn infants. Acta Paediatr 81:812-819

6. Klebermass K, Kuhle S, Kohlhauser-Vollmuth C, Pollak A, Weninger M 2001 Evaluation of the cerebral function monitor as a tool for neurophysiological surveillance in neonatal intensive care patients. Childs Nerv Syst 17:544-550

7. Thiringer K, Connell J, Oozeer R, Carter E, Levene M 1986 Comparison between continuous Medilog EEG and cerebral function monitor recordings on infants in neonatal intensive care. Early Hum Dev 14:150-151

8. Toet MC, Van der Meij W, de Vries LS, Uiterwaal CS, van Huffelen KC 2002 Comparison between simultaneously recorded amplitude integrated electroencephalogram (cerebral function monitor) and standard electroencephalogram in neonates. Pediatrics 109:772-779

9. Connell J, de Vries L, Oozeer R, Regev R, Dubowitz LM, Dubowitz V 1988 Predictive value of early continuous electroencephalogram monitoring in ventilated preterm infants with intraventricular hemorrhage. Pediatrics 82:337-343

10. Eken P, Toet MC, Groenendaal F, de Vries LS 1995 Predictive value of early neuroimaging, pulsed Doppler and neurophysiology in full term infants with hypoxicischaemic encephalopathy. Arch Dis Child Fetal Neonatal Ed 73:F75-F80

11. Thornberg E, Ekstrom-Jodal B 1994 Cerebral function monitoring: a method of predicting outcome in term neonates after severe perinatal asphyxia. Acta Paediatr 83:596-601

12. Toet MC, Hellstrom-Westas L, Groenendaal F, Eken P, de Vries LS 1999 Amplitude integrated EEG 3 and 6 hours after birth in full term neonates with hypoxic-ischaemic encephalopathy. Arch Dis Child Fetal Neonatal Ed 81:F19-F23

13. Hajak G, Klingelhofer J, Schulz-Varszegi M, Matzander G, Sander D, Conrad B Ruther E 1994 Relationship between cerebral blood flow velocities and cerebral electrical activity in sleep. Sleep 17:11-19

14. Klingelhofer J, Hajak G, Matzander G, Schulz-Varszegi M, Sander D, Ruther E, Conrad B 1995 Dynamics of cerebral blood flow velocities during normal human sleep. Clin Neurol Neurosurg 97:142-148

15. Bode H 1992 Intracranial blood flow velocities during seizures and generalized epileptic discharges. Eur J Pediatr 151:706-709

16. Klingelhofer J, Bischoff C, Sander D, Wittich I, Conrad B 1991 Do brief bursts of spike and wave activity cause a cerebral hyper- or hypoperfusion in man? Neurosci Lett 127:77-81

17. Ances BM, Zarahn E, Greenberg JH, Detre JA 2000 Coupling of neural activation to blood flow in the somatosensory cortex of rats is time-intensity separable, but not linear. J Cereb Blood Flow Metab 20:921-930

18. Harada J, Takaku A, Endo S, Kuwayama N, Fukuda O 1991 Differences in critical cerebral blood flow with age in swine. J Neurosurg 75:103-107

19. Van Os S, Klaessens J, Hopman J, Liem D, Van de Bor M 2003 Preservation of electrocortical brain activity during hypoxemia in preterm lambs. Exp Brain Res 151:54-59

20. Dorrepaal CA, Shadid M, Steendijk P, Van der Velde ET, Van de Bor M, Baan J, Van Bel F 1997 Effect of post-hypoxic-ischemic inhibition of nitric oxide synthesis on cerebral blood flow, metabolism and electrocortical brain activity in newborn lambs. Biol Neonate 72:216-226

21. Van Os S, De Abreu R, Hopman J, Wethly K, Liem D, Van de Bor M 2004 Purine and pyrimidine metabolism and electrocortical brain activity during hypoxemia in near-term lambs. Pediatr Res 55:1018-1025

22. Nijland R, Ringnalda B, Jongsma HW, Oeseburg B, Zijlstra WG 1994 Measurement of oxygen saturation by multiwavelength analyzer influenced by interspecies differences. Clin Chem 40:1971

23. Van Bel F, Roman C, Klautz RJ, Teitel DF, Rudolph AM 1994 Relationship between brain blood flow and carotid arterial flow in the sheep fetus. Pediatr Res 35:329-333

24. Hellstrom-Westas L, De Vries LS, Rosen I 2003 An Atlas of Amplitude Integrated EEGs in the Newborn. Parthenon Publishing, New York, pp 1-150

25. Altman DG 1999 Practical Statistics for Medical Research. Chapman \& Hall, London, pp 299-306

26. van de Bor M, Meinesz JH, Benders MJ, Steendijk P, Cardozo RH, van Bel F 1999 Electrocortical brain activity during hypoxia and hypotension in anesthetized newborn lambs. Early Hum Dev 55:237-245

27. Raju TN 1992 Some animal models for the study of perinatal asphyxia. Biol Neonate 62:202-214

28. Baldwin BA, Bell FR 1963 The anatomy of the cerebral circulation of the sheep and ox. The dynamic distribution of the blood supplied by the carotid and vertebral arteries to cranial regions. J Anat 97:203-215

29. Gratton R, Carmichael L, Homan J, Richardson B 1996 Carotid arterial blood flow in the ovine fetus as a continuous measure of cerebral blood flow. J Soc Gynecol Investig 3:60-65
30. Meadow W, Rudinsky B, Raju T, John E, Fornell L, Shankararao R 1999 Correlation of flow probe determinations of common carotid artery blood flow and internal carotid artery blood flow with microsphere determinations of cerebral blood flow in piglets. Pediatr Res 45:324-330

31. Ashwal S, Dale PS, Longo LD 1984 Regional cerebral blood flow: studies in the fetal lamb during hypoxia, hypercapnia, acidosis, and hypotension. Pediatr Res 18:13091316

32. Muller T, Lohle M, Schubert H, Bauer R, Wicher C, Antonow-Schlorke I, Sliwka U, Nathanielsz PW, Schwab M 2002 Developmental changes in cerebral autoregulatory capacity in the fetal sheep parietal cortex. J Physiol 539:957-967

33. Szymonowicz W, Walker AM, Yu VY, Stewart ML, Cannata J, Cussen L 1990 Regional cerebral blood flow after hemorrhagic hypotension in the preterm, nearterm, and new-born lamb. Pediatr Res 28:361-366

34. Tweed WA, Cote J, Pash M, Lou H 1983 Arterial oxygenation determines autoregulation of cerebral blood flow in the fetal lamb. Pediatr Res 17:246-249

35. Van Bel F, Bartelds B, Teitel DF, Rudolph AM 1995 Effect of indomethacin on cerebral blood flow and oxygenation in the normal and ventilated fetal lamb. Pediatr Res 38:243-250

36. Panerai RB, Kelsall AW, Rennie JM, Evans DH 1995 Cerebral autoregulation dynamics in premature newborns. Stroke 26:74-80

37. Pichler G, van Boetzelar MC, Muller W, Urlesberger B 2001 Effect of tilting on cerebral hemodynamics in preterm and term infants. Biol Neonate 80:179-185

38. Tsuji M, Saul JP, Du Plessis A, Eichenwald E, Sobh J, Crocker R, Volpe JJ 2000 Cerebral intravascular oxygenation correlates with mean arterial pressure in critically ill premature infants. Pediatrics 106:625-632

39. Tyszczuk L, Meek J, Elwell C, Wyatt JS 1998 Cerebral blood flow is independent of mean arterial blood pressure in preterm infants undergoing intensive care. Pediatrics 102:337-341

40. Kissack CM, Garr R, Wardle SP, Weindling AM 2004 Cerebral fractional oxygen extraction in very low birth weight infants is high when there is low left ventricular output and hypocarbia but is unaffected by hypotension. Pediatr Res 55:400-405

41. Greisen G 1997 Cerebral blood flow and energy metabolism in the newborn. Clin Perinatol 24:531-546

42. Volpe JJ 2001 Neurology of the Newborn. WB Saunders, Philadelphia

43. Laudignon N, Beharry K, Farri E, Aranda JV 1991 The role of adenosine in the vascular adaptation of neonatal cerebral blood flow during hypotension. J Cereb Blood Flow Metab 11:424-431

44. Humphrey PR, Du Boulay GH, Marshall J, Pearson TC, Russell RW, Symon L, Wetherley-Mein G, Zilkha E 1979 Cerebral blood flow and viscosity in relative polycythaemia. Lancet 2:873-877

45. Jones MD Jr, Traystman RJ, Simmons MA, Molteni RA 1981 Effects of changes in arterial O2 content on cerebral blood flow in the lamb. Am J Physiol 240:H209-H215

46. O’Neill JT, Golden SM, Franklin GA, Alden ER 1994 Cerebral vascular response to hemorrhagic hypotension in newborn lambs: the influence of developing anemia. Proc Soc Exp Biol Med 205:132-139

47. Gunn AJ, Parer JT, Mallard EC, Williams CE, Gluckman PD 1992 Cerebral histologic and electrocorticographic changes after asphyxia in fetal sheep. Pediatr Res 31:486-491

48. Pressler RM, Boylan GB, Morton M, Binnie CD, Rennie JM 2001 Early serial EEG in hypoxic ischaemic encephalopathy. Clin Neurophysiol 112:31-37

49. Sinclair DB, Campbell M, Byrne P, Prasertsom W, Robertson CM 1999 EEG and long-term outcome of term infants with neonatal hypoxic-ischemic encephalopathy. Clin Neurophysiol 110:655-659

50. Thornberg E, Thiringer K 1990 Normal pattern of cerebral function monitor trace in term and preterm neonates. Acta Paediatr Scand 79:20-25

51. Viniker DA, Maynard DE, Scott DF 1984 Cerebral function monitor studies in neonates. Clin Electroencephalogr 15:185-192

52. Carlsson C, Hagerdal M, Siesjo BK 1975 Increase in cerebral oxygen uptake and blood flow in immobilization stress. Acta Physiol Scand 95:206-208

53. Burrows FA, Norton JB, Fewel J 1986 Cardiovascular and respiratory effects of ketamine in the neonatal lamb. Can Anaesth Soc J 33:10-15

54. Akeson J, Bjorkman S, Messeter K, Rosen I, Helfer M 1993 Cerebral pharmacodynamics of anaesthetic and subanaesthetic doses of ketamine in the normoventilated pig. Acta Anaesthesiol Scand 37:211-218

55. Stork EK, Carlo WA, Kliegman RM, Faranoff AA 1984 Hypertension redefined for critically ill neonates. Pediatr Res 18:321A

56. Versmold HT, Kitterman JA, Phibbs RH, Gregory GA, Tooley WH 1981 Aortic blood pressure during the first 12 hours of life in infants with birth weight 610 to 4,220 grams. Pediatrics 67:607-613 